\title{
Legal Protection of Ulayat Rights: Contextualization and Policies
}

\author{
Candra Perbawati ${ }^{1}$, Malicia Evendia ${ }^{2}$ \\ \{chandra.perbawati@fh.unila.ac.id ${ }^{1}$, malicia.evendia@fh.unila.ac.id² \\ Faculty of Law Lampung University, Indonesia ${ }^{12}$
}

\begin{abstract}
The constitution has mandated that the existence of customary law communities and their rights as long as they live still be recognized and respected. This was supported by various national and sectoral laws and regulations which also recognized and respected the customary rights of indigenous peoples, but in its implementation customary land conflicts continue to occur. From the legal aspect, this condition occurs because there is no legal umbrella to protect the existence of customary law communities at the regional level. This research was conducted to protecting of ulayat lands of customary communities with doctrinal legal research methods. The results of this study show that First, regional authority in protecting indigenous peoples is obtained from two legal regimes, the regional government legal regime in Law No. 23 of 2014 concerning Regional Government and sectoral legal regimes in the fields of land, forestry and human rights. Second, the contextualization of legal protection of ulayat land rights for customary law communities by local governments can be done by establishing a Regional Regulation as a Legal Policy, so that local governments are advised to immediately form regulations that contain and protect customary land rights for customary law community.
\end{abstract}

Keywords: contextualization; community; adat; ulayat; protection

\section{Introduction}

Since the beginning of independence efforts have been made to realize the national of legal system, including the unification of laws in the agrarian field. National agrarian law was deliberately worked out at the earliest, considering that from this agrarian problem the Indonesian people were involved in various social, political and legal struggles. Agrarian and the resources in it are always the object of struggle for control and ownership, both among fellow citizens, groups, indigenous peoples, kingdoms, and even the state. Occupation of Indonesia by foreign countries was also in the framework of the agrarian control. Therefore, it is wise when we are free, so the main concern is prioritized to regulate the agrarian problem. On the one hand, the existence of national agrarian law is expected to increase the prosperity of all Indonesian people, while on the other hand the existence of national agrarian law is a means of anticipating the emergence of various conflicts of ownership and control.

The main points of regulation of national agrarian law are in Law No. 5 of 1960 concerning Basic Agrarian Principles (UUPA). There is no denying that the UUPA is a product of legislation that is able to survive for quite a long time, amidst the turmoil and changes in social, political and power regimes in this country. However there are so many demands to change and even replace the UUPA under the pretext of agrarian reform, the 
reality of the UUPA until today is still strong, intact and valid. This does not seem possible, unless the UUPA has strong and deep roots in the life of the Indonesian nation. These strong and deep roots include noble values from which national agrarian law is built with arable objects including earth, water, space, and natural wealth contained in it, as is commonly called agrarian (Indonesian earth). Customary land is one of the main points stipulated in the regulation.

The legal policy of customary land rights, in its implementation, has not provided justice for indigenous people, which has a broad impact on indigenous people because the law cannot work properly, resulting in conflict, besides this, indigenous peoples lose their rights constitutional. Based on the results of the agrarian consortium the report obtained in 2015 agrarian conflict in the country continues to show an increase from 472 cases that occurred, there are several cases related to the issue of land rights of customary law communities or ulayat land which until now has not been resolved. One example is Mesuji Regency, Lampung Province. Problems experienced in Mesuji Regency, Lampung Province, namely there are several implementing regulations that are inconsistent, as in the Lampung Governor's Regulation N0.G / 127 / DA / HK / 1974 and Minister of Forestry Decree No. 0688 / Kpts11/1991 Jo No. 93.KPTS-11/1997 and updated with Minister of Forestry Decree No.322 / Kpts-11/2004 concerning HPHTI. This resulted in the ulayat rights of the Mesuji traditional law community being ignored or lost.

Based on the above conditions, it shows that the state in this case the government has not been able to fully implement efforts to protect the rights of communal land of customary law communities. The many disputes over customary land rights of customary law communities that occur show that the law has not been able to achieve its objectives in accordance with its basic values, namely for justice, benefit and certainty, both in its existence and in its implementation. Therefore there is a need for contextualization of legal protection to provide efforts to recognize and protect the rights to customary land of customary law communities. The legal policy on the protection of customary land rights of the new customary law community is expected to be able to protect the rights to ulayat land of customary law communities and can resolve conflicts over customary land rights that occur in customary law communities.

The role of the regional government as the executor of autonomy authority in the regions must also take responsibility in resolving various problems in the region including regarding the protection of customary land rights. The philosophy of autonomous authority must be understood as an authority to improve the welfare of the people, including indigenous peoples. In this regard, this paper will map and describe an analysis of the role of local governments in providing protection for the rights of indigenous and tribal peoples. To describe the focus of this research the formulation of the problem is formulated as follows:

1. What is the authority of the region in carrying out legal protection for indigenous peoples?

2. What is the contextualization of legal protection of customary land rights for indigenous peoples by the local government?

\section{Method}

This research is done in 2018 and used corridor of doctrinal research which only use secondary data. The legal research model is a comprehensive and analytical study of primary 
legal materials and secondary legal materials. The problem approach uses a statutory approach and a conceptual approach. The data were analyzed qualitatively by describing the data generated from the research into the form of explanation systematically so as to obtain a clear picture of the problem under study, the results of data analysis then concluded deductively.

\section{Results and Discussion}

\subsection{Regional Authority in Protecting Customary Law Communities}

According to Bagir Manan, authority in legal language is not the same as power (macht). Power only describes the right to do or not act. In law, authority also means rights and obligations (rechten en plichten). Philipus M. Hadjon argues that authority is obtained through three sources, namely: attribution, delegation, and mandate. The authority for attribution is usually outlined through the distribution of state power by the Constitution, the authority of delegations and mandates is the authority that comes from delegation. The delegation according to Hadjon, citing Article 10: 3 AWB, delegates is defined as the transfer of authority (to make "besluit") by government officials to other parties and that authority is the responsibility of the other party. The definition of mandate according to Hadjon is a delegation of authority to subordinates.

Authority will give birth to government actions. For this reason, it is also necessary to explain the bestuurhandeling. In order to guarantee and provide a legal basis that government action (bestuurhendeling) carried out by the government as a legitimate and justified act, can be accountable and responsible and liable, then every act of the government must be based on the law that is fair, dignified and democratic.

As an entry point in carrying out an analysis of regional authority in carrying out legal protection for indigenous peoples, it is necessary to map relevant laws and regulations to get a clear picture. The study of the laws and regulations is intended to determine the legal conditions or legislation governing the substance of the regulation of rights to communal land. In this description we will know the position of regional authority in providing protection for indigenous peoples. This analysis will illustrate the synchronization, harmonization of existing legislation and the position of regional authority. The mapping will be described in the following table one.

Table 1. Mapping of Regional Authority for the Protection of Customary Law Communities and Ulayat rights in the Laws

\begin{tabular}{|l|l|l|}
\hline No. & \multicolumn{1}{|c|}{ Rules } & \multicolumn{1}{c|}{ Substance Analysis } \\
\hline 1 & $\begin{array}{l}\text { Basic Constitution } \\
\text { of the Unitary } \\
\text { Republic } \\
\text { Indonesia 1945 of }\end{array}$ & $\begin{array}{l}\text { Article 18 paragraph (6) "The regional government has the right } \\
\text { to stipulate regional regulations and other regulations to carry } \\
\text { out autonomy and assistance tasks." } \\
\text { Article 18B Paragraph (2) which states that "The State } \\
\text { recognizes and respects customary law community units along } \\
\text { with their traditional rights insofar as they are still alive and in } \\
\text { accordance with the development of society and the principles } \\
\text { of the Unitary State of the Republic of Indonesia, which are } \\
\text { regulated in law" } \\
\text { Article 28 I paragraph (3): Cultural identity and rights of }\end{array}$ \\
\hline
\end{tabular}




\begin{tabular}{|c|c|c|}
\hline & & $\begin{array}{l}\text { traditional communities are respected in line with the } \\
\text { development of the times and civilizations. }\end{array}$ \\
\hline 2 & $\begin{array}{ll}\text { Law Number } 23 \\
\text { Year } 2014 \\
\text { concerning } \\
\text { Regional } \\
\text { Government }\end{array}$ & $\begin{array}{l}\text { Broadly speaking, government affairs are divided into absolute } \\
\text { matters which are not autonomous to the regions and both are } \\
\text { concurrent matters, namely government affairs which are } \\
\text { autonomous to the regions concurrently according to the level } \\
\text { of government. Article } 12 \text { then details what constitutes } \\
\text { compulsory government affairs and elected government affairs } \\
\text { which are concurrent matters of regional government: } \\
\text { (1) Mandatory Government Affairs relating to Basic Services as } \\
\text { referred to in Article } 11 \text { paragraph (2) include: } \\
\text { a. education; } \\
\text { b. health; } \\
\text { c. public works and spatial planning; } \\
\text { d. public housing and residential areas; } \\
\text { e. peace, public order and community protection; and } \\
\text { f. social. } \\
\text { (2) Obligatory Government Affairs not related to Basic Services } \\
\text { as referred to in Article } 11 \text { paragraph (2) include: } \\
\text { a. labor; } \\
\text { b. women's empowerment and child protection; } \\
\text { c. food; } \\
\text { d. land; } \\
\text { e. living environment; } \\
\text { f. population administration and civil registration; } \\
\text { g. community and village empowerment; } \\
\text { h. population control and family planning; } \\
\text { i. transportation; } \\
\text { j. communication and informatics; } \\
\text { k. cooperatives, small and medium enterprises; } \\
\text { l. capital investment; } \\
\text { m. youth and sports; } \\
\text { a. statistics; } \\
\text { o. coding; } \\
\text { p. culture; } \\
\text { q. library; and } \\
\text { r. filing. } \\
\text { (3) Preferred Governmentity of the Regency/City Regional Government related to } \\
\text { paragraph (1) include: } \\
\text { a. marine and fisheries; } \\
\text { b. tourism; } \\
\text { c. agriculture; } \\
\text { d. forestry; } \\
\text { e. energy and Mineral Resources; } \\
\text { f. inding; }\end{array}$ \\
\hline
\end{tabular}




\begin{tabular}{|c|c|c|}
\hline & & $\begin{array}{l}\text { the protection of the rights of customary law communities in the } \\
\text { field of affairs as attached to the Annex to this law: } \\
\text { Land Affairs } \\
\text { Sub-Ulayat Land Affairs Sub-authority for Determination of } \\
\text { Ulayat Land located within the regency / city area. } \\
\text { Government Affairs in the Environment } \\
\text { Sub Affairs Recognition of the existence of customary law } \\
\text { communities (MHA), local wisdom and MHA rights related to } \\
\text { PPLH Authority Determination of recognition of MHA, local } \\
\text { wisdom or traditional knowledge and rights of local wisdom or } \\
\text { traditional knowledge and MHA rights related to PPLH in } \\
\text { district/city . b. Increasing the capacity of MHA, local wisdom } \\
\text { or traditional knowledge and local wisdom rights or traditional } \\
\text { knowledge and MHA rights related to PPLH in the district / city } \\
\text { area. } \\
\text { Government Affairs for Community and Village } \\
\text { Empowerment } \\
\text { Sub Affairs of community institutions, customary institutions, } \\
\text { and customary law communities Authority to empower } \\
\text { community organizations engaged in village empowerment and } \\
\text { customary institutions at the district/city level and empowering } \\
\text { customary law communities that have the same customary law in } \\
\text { the district/city. b. Empowerment of community institutions } \\
\text { and traditional institutions at the village level. } \\
\text { From the provisions above, it can be seen that government } \\
\text { affairs are the source of authority of the regional government as } \\
\text { a basis for the Protection of Customary Rights of the Customary } \\
\text { Law Community. }\end{array}$ \\
\hline 3 & $\begin{array}{l}\text { Law Number } 5 \text { of } \\
1960 \text { concerning } \\
\text { Basic Agrarian } \\
\text { Principles }\end{array}$ & $\begin{array}{l}\text { Article } 3 \text { UUPA } \\
\text { "Customary rights of indigenous peoples are recognized as long } \\
\text { as in reality there are still". }\end{array}$ \\
\hline 4 & $\begin{array}{l}\text { Law Number } 41 \\
\text { Year } 1999 \text { jo Law } \\
\text { Number } 19 \text { Year } \\
2004 \text { concerning } \\
\text { Forestry }\end{array}$ & $\begin{array}{l}\text { CHAPTER IX } \\
\text { INDIGENOUS LEGAL COMMUNITIES } \\
\text { Article } 67 \\
\text { (1) The customary law community insofar as it is in reality still } \\
\text { exists and is recognized as having the right: } \\
\text { a. collecting forest products to fulfill their daily needs } \\
\text { the indigenous peoples concerned; } \\
\text { b. carry out forest management activities based on applicable } \\
\text { customary law and } \\
\text { not contrary to the law; and } \\
\text { c. get empowerment in order to improve their welfare. } \\
\text { (2) Inauguration of the existence and deletion of the customary } \\
\text { law community as referred to in paragraph (1) shall be stipulated }\end{array}$ \\
\hline
\end{tabular}




\begin{tabular}{|c|c|c|}
\hline & & $\begin{array}{l}\text { by Regional Regulation. } \\
\text { Article } 67 \\
\text { Paragraph (1) } \\
\text { The existence of customary law communities is recognized, if } \\
\text { according to reality it fulfills the elements, among others: } \\
\text { a. the community is still in the form of a community } \\
\text { (rechtsgemeenschap); } \\
\text { b. there are institutions in the form of their traditional ruling } \\
\text { device; } \\
\text { c. there are clear areas of customary law; } \\
\text { d. there are institutions and legal instruments, especially } \\
\text { customary justice, } \\
\text { e. who are still obeyed; and } \\
\text { a. still holding collection of forest products in the surrounding } \\
\text { forest area to fulfill their daily needs. } \\
\text { Paragraph } 2 \\
\text { Regional regulations are prepared taking into account the results } \\
\text { of research by indigenous law experts, the aspirations of the } \\
\text { local community, and indigenous community leaders in the area } \\
\text { concerned, as well as other relevant agencies or parties. }\end{array}$ \\
\hline 5 & $\begin{array}{l}\text { Law Number } 39 \\
\text { of } 1999 \\
\text { concerning } \\
\text { Human Rights }\end{array}$ & $\begin{array}{l}\text { Article } 6 \\
\text { (1) In order to uphold human rights, differences and needs in } \\
\text { indigenous and tribal peoples must be considered and protected } \\
\text { by law, society, and the government } \\
\text { (2) Cultural identity of customary law communities including } \\
\text { customary rights is protected, in line with the times. } \\
\text { Explanation of Article } 6 \\
\text { Paragraph (1) } \\
\text { Customary rights that are actually still valid and upheld in the } \\
\text { environment customary law communities must be respected and } \\
\text { protected in the context of protection and enforcement of } \\
\text { human rights in the community concerned pay attention to laws } \\
\text { and regulations. } \\
\text { Paragraph (2) } \\
\text { In order to uphold human rights, the national cultural identity of } \\
\text { the community customary law, customary rights that are still } \\
\text { clearly held by the community local customary law, still } \\
\text { respected and protected insofar as it does not conflict with the } \\
\text { principles of the rule of law which have the essence of justice } \\
\text { and people's welfare. }\end{array}$ \\
\hline 6 & $\begin{array}{lr}\text { MK } & \text { Court } \\
\text { Decision } & \text { No. } \\
\text { 35/PUU-X / } & 2012\end{array}$ & $\begin{array}{l}\text { In its decision, the Constitutional Court canceled a number of } \\
\text { words, phrases and verses in the Forestry Law. For example, the } \\
\text { Constitutional Court deleted the word "country" in Article } 1 \\
\text { number } 6 \text { of the Forestry Law, so Article } 1 \text { point } 6 \text { of the } \\
\text { Forestry Law became "Customary forests are forests within the } \\
\text { territory of indigenous peoples." The Court also interpreted the } \\
\text { provisions of Article } 5 \text { paragraph (1) of the Forestry Law insofar } \\
\text { as it is not interpreted "State forest as referred to in paragraph }\end{array}$ \\
\hline
\end{tabular}




\begin{tabular}{|c|c|c|}
\hline & & 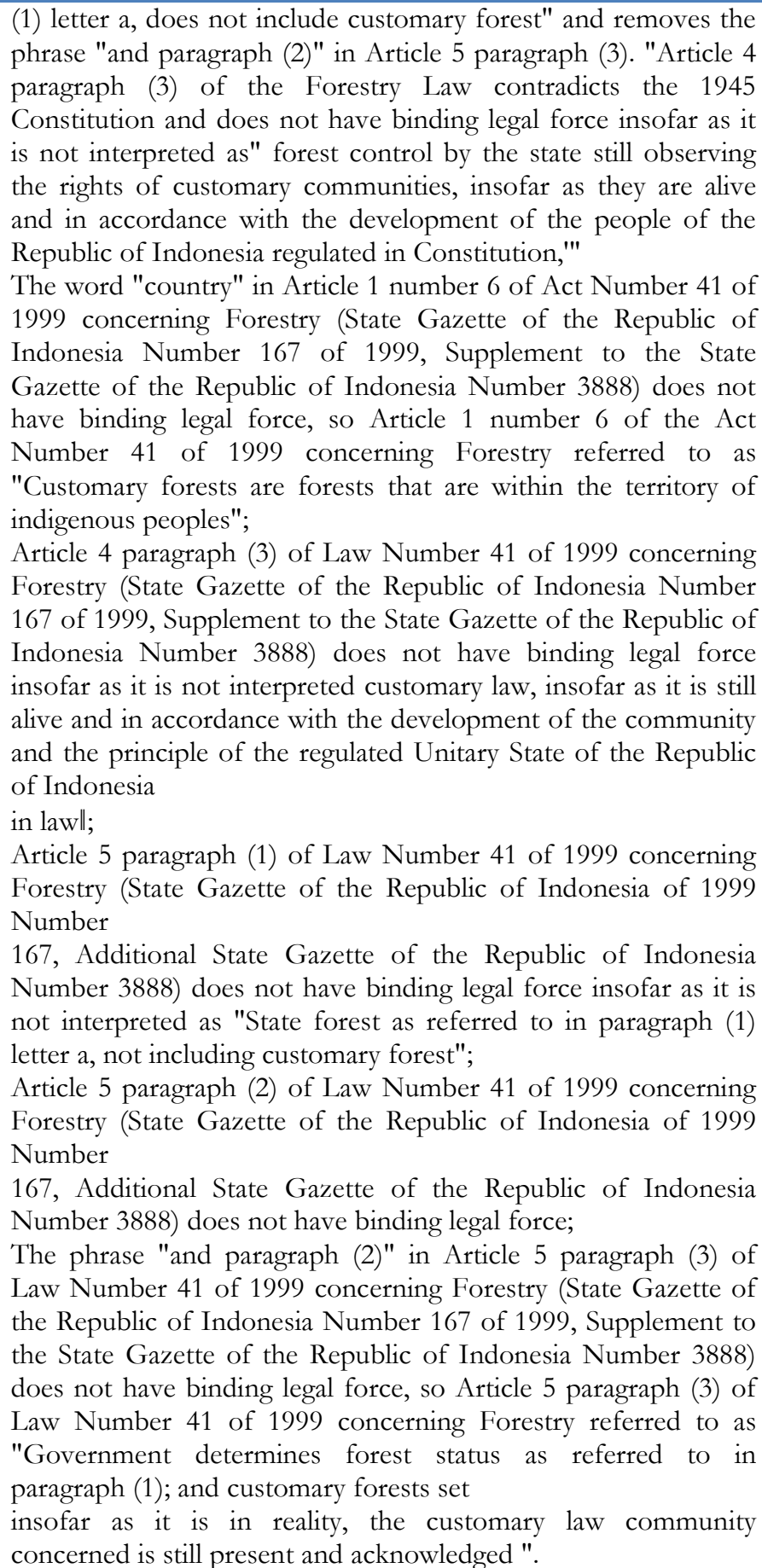 \\
\hline 7 & $\begin{array}{l}\text { Minister of Home } \\
\text { Affairs Regulation }\end{array}$ & $\begin{array}{l}\text { Article 2: Governors and regents / mayors recognize and protect } \\
\text { customary law communities. }\end{array}$ \\
\hline
\end{tabular}




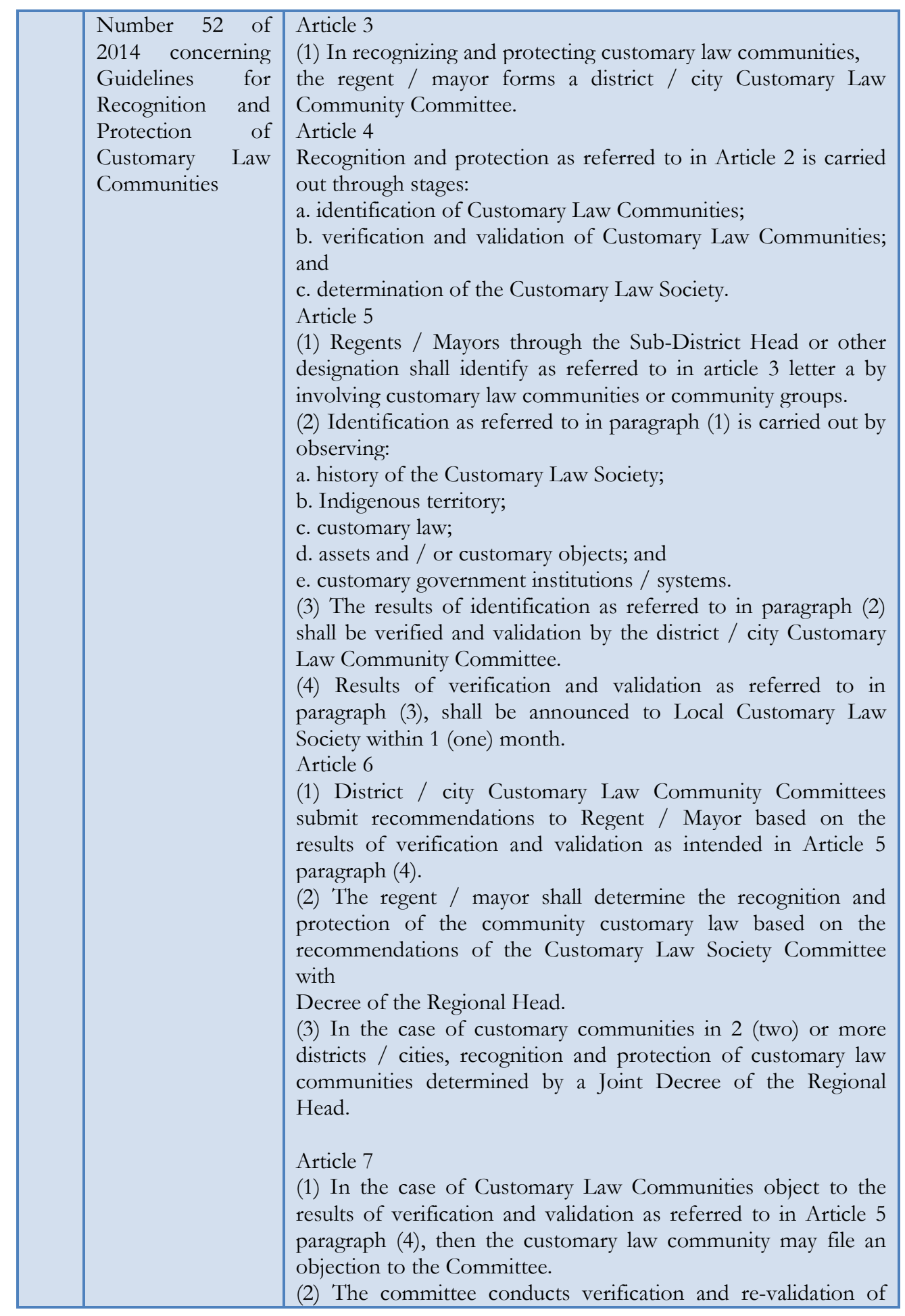




\begin{tabular}{|c|c|c|}
\hline & & $\begin{array}{l}\text { community objections as referred to in paragraph (1). } \\
\text { (3) Verification and re-validation of community objections can } \\
\text { only be done } 1 \text { (one) time. } \\
\text { Article } 8 \\
\text { (1) In the case of the Customary Law Society objection to the } \\
\text { Decree of the Regional Head as referred to in Article } 6 \\
\text { paragraph (2) and paragraph (3), can submit objection to the } \\
\text { State Administrative Court. } \\
\text { (2) Settlement of the dispute over the filing of an objection as } \\
\text { referred to in paragraph (1) is carried out in accordance with the } \\
\text { provisions of the legislation. }\end{array}$ \\
\hline 8 & 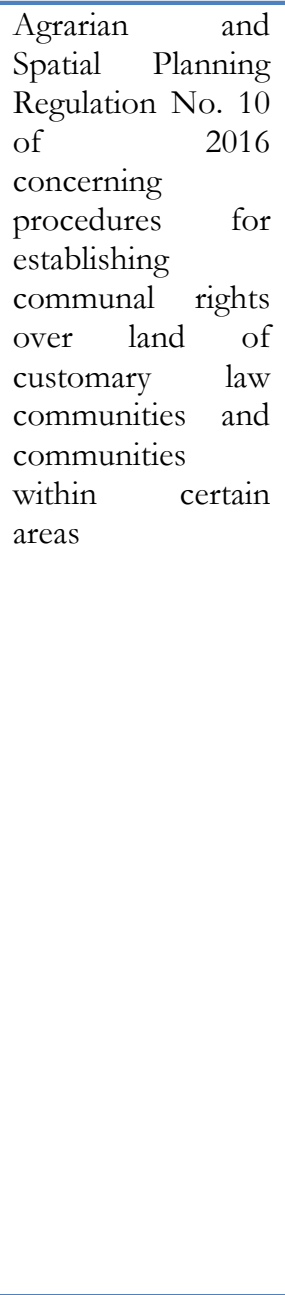 & $\begin{array}{l}\text { Communal rights to land, are joint property rights to the land of } \\
\text { a customary law community, or joint property rights to land } \\
\text { granted to communities within a certain area. } \\
\text { MHA is a group of people who are bound by their customary } \\
\text { law as citizens together with a legal alliance because of the } \\
\text { similarity of place of residence or on the basis of descent. } \\
\text { Article } 2 \text { paragraph 1, customary communities that fulfill the } \\
\text { requirements can be confirmed the rights to their land. } \\
\text { Article } 4 \text { paragraph } 1 \\
\text { The requirements of the customary law community as referred } \\
\text { to in article } 2 \text { paragraph } 1 \text { include: } \\
\text { a. The community is still in the form of a community; } \\
\text { b. There are institutions within the ruler's customary } \\
\text { instruments; } \\
\text { c. There are clear areas of customary law; and } \\
\text { d. There are institutions and legal instruments, which are still } \\
\text { adhered to. } \\
\text { Article } 5 \text { paragraph } 1 \\
\text { Customary law communities or communities in certain areas } \\
\text { submit applications to regents / mayors or governors. } \\
\text { Article } 6 \text { paragraph } 1 \\
\text { In the case of the land requested in } 1 \text { (one) district / city, the } \\
\text { regent / mayor forms an IP4T team. Article } 7 \text {, The IP4T Team } \\
\text { has the duty: to accept the application; identify and verify the } \\
\text { applicant, land history, type, control, use and use of land; } \\
\text { identify and inventory land boundaries; field inspection; analyze } \\
\text { juridical data and physical data on parcels of land; and submit } \\
\text { reports on the work of the IP4T team. } \\
\text { Article } 18 \text {, in the event that the report states the existence of } \\
\text { customary law communities and their land, the regent / mayor } \\
\text { determines the existence of customary law communities and } \\
\text { their land, in the case that land is located in } 1 \text { (one) district / } \\
\text { city. }\end{array}$ \\
\hline
\end{tabular}

Based on the description in table one, it can be seen that there is harmonization and synchronization which shows that the local government has the authority to protect and empower indigenous peoples. The authority of the Regional Government in protecting indigenous peoples is based on two legal regimes at the same time, namely the regional 
government legal regime outlined in Law No. 23 of 2014 concerning Regional Government and sectoral legal regimes spread in the fields of land, forestry and human rights. The authority is conceptually the authority that is attributed because it is directly outlined by the Act. From these laws and regulations, the Regional Government has the authority to make regional policies related to the protection of customary law communities which are ideally set forth in regional regulations as the basis for legitimacy for the protection of customary law communities.

\subsection{Contextualization of Legal Protection of the Ulayat Right for Customary Law Communities by the Regional Government}

The constitution as the highest legal source has mandated that the existence of customary law communities and their rights as long as they live still be recognized and respected. This was then supported by various national and sectoral laws and regulations which also recognized and respected the customary rights of customary law communities, including: Law Number 5 of 1960 concerning Basic Agrarian Basic Regulations, Law Number 39 of 1999 concerning Human Rights, Minister of Environment and Forestry Regulation No. P.32 / Menlhk Secretariat of 2015 concerning Forest Rights, Agrarian Regulation and Spatial Planning No. 10 of 2016 concerning procedures for establishing communal rights, and other sectoral regulations. The government's political will in maintaining the existence of indigenous peoples is also strengthened by the existence of the Constitutional Court Decision No. 35 / PUU-X / 2012, which has canceled some of the provisions in Law No. 41 of 1999 concerning Forestry which are the source of the emergence of dishonorable policy regulations, so that the existence of these decisions is that customary forests are no longer part of State forests.

Even though the customary rights of indigenous peoples have been recognized in various laws and regulations, but in its implementation to date customary land conflicts continue to occur. From the legal aspect, this condition occurs because there is no legal umbrella to protect the existence of customary law communities at the regional level. Therefore, the concrete role of regional governments is urgently needed in the formation of regional regulations related to the protection of customary rights of indigenous and tribal peoples. The formulation of arrangements for the protection of customary land rights for indigenous and tribal peoples in regional regulations will concretize the role of local government and customary law communities to form the following configuration:

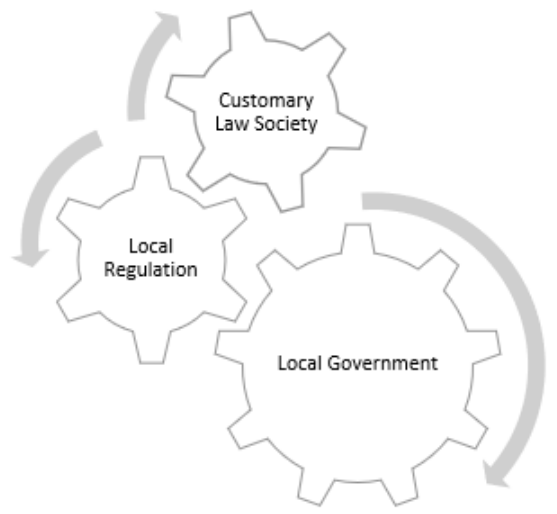

Fig 1. Configuring Charge Synergy Raperda Protection of customary law communities 
The existence of local regulations on the protection of customary land rights for customary law communities in accordance with the legal function to maintain public and individual interests in the state and direct the actions or decisions of the state and people to realize the ideals of justice, truth and prosperity in the country. With the legal protection of the right to communal land for indigenous peoples who are just, it is hoped that it will be able to protect indigenous groups in the area.

In addition, according to Von Savigny (1779-1861) that the regime and legal doctrine made by the government differed from local law. Next he said that the law was the People's Soul. Construction of von Savigny's theory of the law that there is an organic relationship between the law and the character or character of a nation. Reflecting the law of the Volkgeist, therefore customary law that grows and develops in a volkgeist regime must be seen as a law of true life. True law is not made, but found. Legislation is important as long as it has the declarative nature of the true law. So that law is a mirror of society, the law that is built must be a reflection of the character or character of a society.

Establishment of a law on the protection of customary land rights for indigenous peoples as a formulation of substance and legal institutional structure. Through this regulation, the protection of customary land rights of customary law communities can be carried out. Formulation of Legal Protection of customary land rights for indigenous and tribal peoples with a human rights perspective using the Prismatic Society-FW Riggs Concept. The legal concept of the Prismatic Society is the concept of law as a middle way of resolving two cultural problems found in society. In society there are two cultures, namely those based on the community (gemainchaft) and patembayan (gezelschaft). The formulation of legal protection for customary land rights for indigenous people is a harmonious law that combines the values of national land law with customary law. In accordance with the concept of the Primmatic Society or the concept of the Prismatic community, that the formulation of the Regional Regulation on Legal Protection of the rights to communal land for indigenous peoples is a middle ground in overcoming the problems at hand.

\section{Conclusions}

\subsection{Conclusion}

Based on the results of the discussion, it can be concluded the following: First, regional authority in protecting indigenous peoples is obtained from two legal regimes, namely the regional government legal regime outlined in Law No. 23 of 2014 concerning Regional Government and sectoral land law regime, forestry and human rights. Second, the contextualization of legal protection of customary land rights for customary law communities by the local government can be done by the establishment of a Regional Regulation as a Legal Policy for the Protection of Property Rights on the Land of Customary Law Communities

\subsection{Recommendation}

The regional government must immediately form regional regulations as contextualization of the role of the content of recognizing and protecting customary land rights for customary law communities. 


\section{References}

[1] Bewa Ragawino, (2008). Hukum Administrasi Negara, (Administrative Law), Soft File.

[2] Hadjon, Philipus M. (1994). Fungsi Normatif Hukum Administrasi Dalam Mewujudkan Pemerintahan Yang Bersih. (Normative Function of Administrative Law in Realizing Clean Government), delivered at the Professor's inaugural Speech in FH UNAIR.

[3] Hadjon, Philipus M. (1997). Tentang Wewenang, (About Authority) "Yuridika" FH Universitas Airlangga, No. 5 dan 6 Tahun XII.

[4] HR, Ridwan. (2006). Hukum Administrasi Negara, (Administrative Law), Jakarta: PT Raja Grafindo.

[5] Mahmud, Peter. (2005). Penelitian Hukum (Legal Research), Kencana Prenada, Jakarta.

[6] Manan, Bagir. (2000). Wewenang Provinsi, Kabupaten dan Kota Dalam Rangka Otonomi Daerah, (Provincial, Regency and City Authority in the Context of Regional Autonomy) Makalah pada Seminar Nasional FH UNPAD.

[7] Rigss, Fred W. (1964). Administration in Developing Countries, The Theory of Prismatic Society, Hought Miffin Company, Boston.

[8] Tanya, Bernard L. dkk. (2013). Teori Hukum Strategi Tertib Manusia Lintas Ruang dan Generasi, (Legal Theory of Cross-Space and Generational Human Order Strategy), Genta publishing, Yogyakarta.

[9] Tutik, Titik Triwulan. (2010). Konstruksi Hukum Tata Negara Indonesia Pasca Amandemen UUD 1945 (Construction of Indonesian Constitutional Law Post-Amendment to the 1945 Constitution), Jakarta: Kencana.

[10] Winahyu, 2004. Peranan Hukum Dalam Pertanggungjawaban Perbuatan Pemerintahan (Bestuurhandeling) Suatu Kajian Dalam Kebijakan Pembangunan Hukum (The Role of the Law In the Accountability of Government Actions (Bestuurhandeling) A Study in Legal Development Policy), Jurisprudence, Vol. 1, No. 2. 